\title{
First report of oligacanthorhynchus microcephalus (rudolphi, I819) (acanthocephala: oligacanthorhynchidae) in didelphis albiventris (lund, I84I) (marsupialia: didelphidae) in Southeastern Brazil
}

\begin{abstract}
Although acanthocephalan parasites were discovered many decades ago, very little is known about their epidemiology, biology, pathogenicity and economic impact. Didelphids (opossums) are primitive animals with opportunistic and synanthropic habits, which have a predisposition to infectious endoparasites due to their omnivorous eating habits. Two female specimens of Didelphis albiventris were necropsied at the Wild Animal Screening Center (CETAS) of the Brazilian Institute of Environment and Renewable Natural Resources (IBAMA) in the Municipality of Juiz de Fora, state of Minas Gerais, Brazil. The macroscopic analysis revealed the presence of a single acanthocephalan worm, $150.0 \mathrm{~mm}$ long and $7.0 \mathrm{~mm}$ wide, $98.0 \mathrm{~mm}$ long and $4.0 \mathrm{~mm}$ wide, in the small intestine of each opossum. A parasitological analysis showed that the worms had white, pleated, fusiform, spiral-shaped bodies with marked transverse wrinkles, a proboscis broadly armed with six longitudinally arranged spiral rows of six shallowly rooted hooks each, making a total of 36 hooks, all features compatible with Oligacanthorhynchus microcephalus. To the best of our knowledge, this paper offers the first report of natural infection of $D$. Albiventris by $O$. Microcephalus in the state of Minas Gerais, in southeastern Brazil. However, new studies of the helminthic fauna of marsupials are needed in order to further elucidate aspects pertaining to the biological behavior of the parasites, and to estimate the prevalence and impact of these infections in the wild
\end{abstract}

Keywords: acanthocephala, spiny-headed worms, thorny-headed worms, Oligacanthorhynchus Microcephalus, opossum, Didelphis Albiventris, minas gerais state, southeastern brazil
Volume 5 Issue 3 - 2017

\author{
Álvaro Carneiro de Souza,' Érico Furtado \\ Alvares, ${ }^{2}$ Sarah Stutz Reis, ${ }^{2}$ André Santos \\ Neves, ${ }^{3}$ Glauber Thiago Martins Barino, ${ }^{2}$ \\ Manoel Eduardo da Silva, ${ }^{4}$ Vinicius Novaes \\ Rocha,' Janildo Ludolf Reis Junior,' Sydnei \\ Magno da Silva, ${ }^{5}$ Raul Rio Ribeiro' \\ 'Departamento de Medicina Veterinária, Universidade Federal \\ de Juiz de Fora - UFJF, Brazil \\ ${ }^{2}$ Instituto Estadual de Florestas - IEF, Brasil \\ ${ }^{3}$ Centro de Triagem de Animais Silvestres - CETAS, Instituto \\ Brasileiro do Meio Ambiente e dos Recursos Naturais \\ Renováveis - IBAMA, Brasil \\ ${ }^{4}$ Empresa de Pesquisa Agropecuária de Minas Gerais - EPAMIG, \\ Campo Experimental de Pitangui - ITAC/EPAMIG, Brasil \\ ${ }^{5}$ Departamento de Imunologia, Microbiologia e Parasitologia, \\ Universidade Federal de Uberlândia - UFU, Brasil
}

\begin{abstract}
Correspondence: Raul Rio Ribeiro, Faculdade de Medicina, Departamento de Medicina Veterinária, Universidade Federal de Juiz de Fora-UFJF, Rua: José Lourenço Kelmer, s/n - Campus Universitário, Bairro São Pedro, CEP, 36036 900-Juiz de ForaMG, Brazil,Tel +55 32 2102 685I, Email raul.rio@uff.edu.br
\end{abstract}

Received: January 22, 2017 | Published: May | I, 2017

\section{Introduction}

The first records of acanthocephalan parasites date back to the early 18 th century, but these parasites were not clearly distinguished from other intestinal worms until 1771, when Kölreuter proposed the name Acanthocephalus for a fish parasite. ${ }^{1,2}$ So many decades later, and despite the records of numerous species of acanthocephalan fauna and a wide diversity of hosts, our knowledge about their biological cycles, pathogenicity and economic impact is still very scanty. Acanthocephala is a phylum of pseudocoelomate endoparasitic worms, without a digestive tract, known as thorny-headed worms or spiny-headed worms, which parasitize all groups of vertebrates and some groups of invertebrates. These worms are characterized by the presence of an invaginable proboscis, armed with hooks, which they use to attach to their host.

Marsupials are primitive mammals found only in the Americas and Australia. Among them is the genus Didelphis (Greek meaning "double womb"), which is represented by three groups of opossums comprising six known species, four of which are found in Brazil, namely: the Neotropical black-eared opossums, D. marsupialis and D. Aurita, and the white-eared opossums D. Imperfecta and D. Albiventris. ${ }^{3-5}$ The latter species occurs only in South America and is common in Brazil. Natural habitats of synanthropic animals such as D. Albiventris are becoming progressively compromised, and although they live in close proximity to humans in rural and urban environments, and have an epidemiological potential for the transmission of enzootic and zoonotic agents, their parasitic fauna have not yet been completely established. Studies of the helminth parasites of opossums have been limited mainly to the species $D$. Virginiana and D. Marsupialis. ${ }^{6}$

A study carried out in Argentina evaluated the taxonomic composition and community structure of the parasites collected from 42 individuals of $D$. Albiventris. ${ }^{7}$ The results indicated that the white-eared opossum is highly parasitized all year round by nematodes, cestodes and acanthocephalans, the latter being represented by Oligacanthorhynchus microcephalus (Rudolphi, 1819) Schmidt, 1972 [syns. Echinorhynchus microcephalus Rudolphi, 1819; Echinorhynchus tortuosa Leidy, 1850; Hamanniella microcephala (Rudolphi, 1819) Travassos, 1915; Hamanniella tortuosa (Leidy, 1850) Van Cleave, 1924; Hamanniella tumida (Van Cleave, 1947) Van Cleave, 1953; Oligacanthorhynchus tortuosa (Leidy, 1850) Schmidt, 1972; Oligacanthorhynchus tumida (Van Cleave, 1947) Schmidt, 1972; Travassosia tumida Van 
Cleave, 1947], a satellite species (least frequency) when compared with other helminths such as Turgida turgida (nematode central species). Opossums are opportunistic animals that can feed on a wide range of foods in different environments, e.g., fruits, seeds, sprouts, insects, mollusks, birds, amphibians, reptiles and even small mammals., Their omnivorous diet can predispose opossums to infections by endoparasites, whose intermediate hosts are small arthropods. The millipede Narceus americanus was recently described as an intermediate host of $O$. Microcephalus, ${ }^{10}$ although it is reasonable to assume that there are other as yet unknown intermediate hosts, since the range of parasites significantly exceeds that of arthropods

Although $O$. Microcephalus seems to be recorded frequently in some American countries such as Mexico ${ }^{11-15}$ and Argentina, $7,16,17$ there are only two records of infection in D. albiventris in Brazil, both in the southern part of the country. ${ }^{18,19}$ No previous record exists of didelphids naturally infected with $O$. Microcephalus in southeastern Brazil. ${ }^{6,20-22}$ The aim of this paper therefore is to offer the first report of O. Microcephalus (Rudolphi, 1819) in D. albiventris (Lund, 1841) captured in the state of Minas Gerais, Brazil.

\section{Case presentation}

Two female specimens of $D$. Albiventris were taken to theWild Animal Screening Center of the Brazilian Institute of Environment and Renewable Natural Resources (CETAS/IBAMA) in the Municipality of Juiz de Fora, state of Minas Gerais, Brazil.

\section{Case one}

The animal was still alive but very weak; the clinical examination revealed difficulties in feeding on solids, progressive weight loss during maintenance with a pasty diet, and the presence of five pups in the marsupial's womb. The opossum died ten days after her arrival and was necropsied at the Laboratory of Veterinary Pathology of the Federal University of Juiz de Fora (UFJF). The macroscopic analysis revealed an ulcerated cutaneous lesion of approximately $1.5 \mathrm{~cm}$ in the right temporomandibular region, the presence of multiple mandible fractures and a palatal fracture, which could justify, in part, the clinical signs of dysphagia, in addition to pubic ramus fracture. Furthermore, there were focally extensive hematomas in the left lateral region of the abdomen and marked edema in muscles of the femoral and tibial regions. Taken together, the macroscopic findings suggest a traumatic death probably resulting from being run over or from a fall. Histopathological analyses did not reveal noteworthy findings that could provide additional information. From the standpoint of parasites, only helminths were visible, all recovered from the small intestine and immediately transferred to sample bottles containing $10 \%$ neutral buffered formalin, which were sent to the Laboratory of Veterinary Parasitology of UFJF. The parasites were cleared with lactophenol, after which important morphological parts of the parasites were analyzed under light microscopy and stereoscopic microscopy.

The parasitological analysis revealed two distinct groups of helminths, namely:

i. Nematoda - dozens of specimens of a single species of parasite varying in length from 7.0 to $10.0 \mathrm{~mm}$ and in width from 0.2 to $0.8 \mathrm{~mm}$;

ii. Acanthocephalus - a single specimen measuring $150.0 \mathrm{~mm}$ in length by $7.0 \mathrm{~mm}$ in width. In summary and according to taxonomic keys and descriptions by different authors, ${ }^{23-26}$ the morphological characteristics of the nematodes were consistent with Aspidodera raillieti (Travassos, 1913) (Nematoda: Aspidoderidae), a typical parasite of opossums in Brazil and other parts of the Americas. ${ }^{6,7,18,20,24,26-38}$ The of specimen acanthocephalus had a white, pleated, fusiform, spiral-shaped body with marked transverse wrinkles, and a proboscis broadly armed with six longitudinally arranged spiral rows, each with six shallowly rooted hooks, making a total of 36 hooks, and a well-developed muscular copulatory bursa, roughly orbicular, at the posterior end, all characteristics compatible with a male specimen of $O$. Microcephalus. ${ }^{3,15}$

\section{Case Two}

This animal was already dead upon arrival at CETAS; in fact, it was in an advanced stage of putrefaction, making it impossible to determine the cause of death. In this case too, a single male acanthocephalan specimen was recovered from the same location in the small intestinal, measuring $98.0 \mathrm{~mm}$ in length by $4.0 \mathrm{~mm}$ in width and exhibiting other morphological characteristics similar to those described for $O$. Microcephalus. Parasitism of $D$. Albiventris by $O$. Microcephalus has been reported in countries neighboring Brazil, such as Paraguay ${ }^{39}$ and Argentina, ${ }^{7,16,17}$ based on the analysis of $58 \mathrm{D}$. Albiventris specimens captured in the northeastern region of the country. The literature records just two cases of $D$. Albiventris naturally infected with $O$. Microcephalus in Brazil, both of them in the south. One case occurred in the state of Rio Grande do Sul, ${ }^{18}$ where a single specimen was recovered from the small intestine of one of 30 marsupials (3.33\%) that were examined. The other case, which was reported in the state of Paraná, ${ }^{19}$ was discovered during the necropsy of nine specimens of $D$. Albiventris, but no information was give about the prevalence of infection.

Brazil is divided geopolitically into five regions (North, Northeast, Center-West, Southeast and South), with the Southeast standing out as the country's most developed region. So far, none of the studies conducted in southeastern Brazil have found didelphids infected with $O$. Microcephalus. No acanthocephalans were included among ten species of helminths collected from 22 specimens of white-bellied opossums captured in the region of Pampulha, state of Minas Gerais. ${ }^{6}$ An investigation of the biodiversity of intestinal parasites in wild mammals from the reservoir of Jaguari, located in the municipality of Vargem, state of São Paulo, which involved the necropsy of four $D$. Albiventris, and a coproparasitological analysis (sedimentation and fluctuation methods) of eight specimens of D. Aurita came up with the same findings. ${ }^{21}$ Only nematodes were recovered from the $D$. Aurita opossums captured in the Atlantic Forest in the state of Rio de Janeiro. ${ }^{20}$ Seventeen specimens of $D$. Albiventris were necropsied and 58 fecal samples of Didelphis spp. were analyzed from an urban area and from riparian forest fragments in the Capivari River basin in the municipality of Monte Mor, state of São Paulo, but no evidence of acanthocephalus infection was found. ${ }^{22}$

It was demonstrated that the prevalence value of $O$. Microcephalus increased in spring, whereas mean intensities and relative densities decreased. ${ }^{7}$ Curiously, the host in Argentina was not parasitized during autumn. As expected, these data suggest that the dynamics of infection of $O$. Microcephalus is influenced by climate conditions, which could explain the distribution of the parasite in different regions of a country, especially in times of climate change and in a country of continental dimensions such as Brazil. Moreover, the presence of definitive hosts, the availability of intermediate hosts, 
competition between different parasites, among numerous other factors, also determine the establishment of a parasite in a locality. As far as the authors are aware, this paper offers the first report of natural infection of $D$. Albiventris by $O$. Microcephalus in the state of Minas Gerais, in southeastern Brazil, and also the third national record of such infection. Further studies about the helminthic fauna of marsupials are needed in order to help elucidate aspects related to the biological behavior of these parasites, as well as to estimate the prevalence and impact of these infections in the wild.

\section{Acknowledgements}

The authors wish to express their thanks to all CETAS/IBAMA staff who, directly or indirectly, contributed to this research. We are especially indebted to Prof. Vinicius Novaes Rocha, PhD. (Laboratory of Morphology, Institute of Biological Sciences, Federal University of Juiz de Fora - UFJF) for his kind contribution of the reagents used in this work. This research was supported by the CETAS/IBAMA and the Department of Veterinary Medicine of the Federal University of Juiz de Fora - UFJF.

\section{Conflict of interest}

Author declares that there is no conflict of interest.

\section{References}

1. Hyman LH. The invertebrates. Acanthocephala, aschelminthes, and entoprocta: the pseudocoelomat bilsteria. 1951;3:550.

2. Amin OM. Classification of the Acanthocephala. Folia Parasitol. 2013;60(4):273-305.

3. Richardson DJ, Gardner SL, Allen JW. Redescription of Oligacanthorhynchus microcephalus(Rudolphi, 1819) Schmidt 1972 (syn. Oligacanthorhynchus tortuosa (Leidy, 1850) Schmidt 1972) (Acanthocephala: Oligacanthorhynchidae). Comp Parasitol. 2014;81(1):53-60.

4. Voss RS, Emmons LH. Mammalian diversity in neotropical lowland rainforests: a preliminary assessment. Bull Am Mus Nat Hits. 1996;230:1-115.

5. Malta MCC, Luppi MM. Marsupialia-Didelphimorphia (Gambá, Cuíca). In: Cubas ZS, editor. Tratado de animais selvagens. Roca, Brazil; 2007. p. $340-357$.

6. Silva MGQ, Costa HMA. Helminths of White-bellied Opossum from Brazil. J Wildl Dis. 1999;35(2):371-374.

7. Navone GT, Suriano DM. Species composition and seasonal dynamics of the helminth community parasitizing Didelphis albiventris (Marsupialia: Didelphidae) in savannas of central Argentina. Austral Ecol. 1992;2:95-100.

8. Cáceres NC. Food habits and seed dispersal by the white-eared opossum, Didelphis albiventris, in Southern Brazil. Stud Neotrop Fauna Environ. 2002;37(2):97-104.

9. Ceotto P, Finotti R, Santori R, et al. Diet variation of the marsupials Didelphis aurita and Philander frenatus (Didelphimorphia, Didelphidae) in a rural area of Rio de Janeiro state, Brazil. Mastozool Neotrop. 2009;16(1):49-58.

10. Richardson DJ. Life cycle of Oligacanthorhynchus tortuosa (Oligacanthorhynchidae), an acanthocephalan of the Virginia opossum (Didelphis virginiana). Comp Parasitol. 2006;73(1):1-6.

11. Prado-Ancona JD. Estudio taxonômico De 10 especies De acantocéfalos (Acanthocephala Rudolphi, 1801) De vertebrados De México. Mexico: Universidad Nacional Autónoma de México; 1993.
12. Cañeda-Guzmán C. Parásitos De tres especies De marsupiales De la Estación "Los Tuxtlas" y algunas zonas cercanas, Veracruz, México. Mexico: Universidad Nacional Autónoma de México, 1997.

13. García-Varela M, Pérez-Ponce de León G, De la Torre P, et al Phylogenetic relationships of Acanthocephala based on analysis of $18 \mathrm{~S}$ Ribosomal RNA gene sequences. J Mol Evol. 2000;50(6):532-540.

14. García-Prieto L, García-Varela M, Mendoza-Garfias B, et al. Zootaxa. 2010;2419:1-50

15. López-Caballero J, Mata-López R, García-Varela M, et al. Genetic variation of Oligacanthorhynchus microcephalus (Acanthocephala: Archiacanthocephala: Oligacanthorhynchidae), parasite of three species of opossums (Mammalia: Didelphidae) across central and southeastern Mexico. Comp Parasitol. 2015;82(2):175-186.

16. Martínez FA. Helmintofauna De los mamíferos silvestres, Trematodes Vet Argent. 1986;3(26):544-551.

17. Martínez FA. Zooparasitos De mamíferos silvestres. Vet Argent. 1987;4(33):266-271.

18. Antunes GM. Diversidade e potencial zoonótico de parasitos De Didelphis albiventris (gambá) no Rio Grande do Sul. Brazil: Universidade Federal do Rio Grande do Sul, 2005.

19. Pinto SB, Valentim-Zabott M, Viott AM, et al. Helmintofauna De Didelphis albiventris (Lund, 1841), no município de Palotina, Paraná Brasil. Annals of XVII Congresso Brasileiro de Parasitologia Veterinária. Brasil; 2012. p. 133.

20. Gomes DC, Cruz RP, Vicente JJ, et al. Nematode parasites of marsupials and small rodents from the Brazilian Atlantic Forest in the State of Rio de Janeiro, Brazil. Rev Bras Zool. 2003;20(4):699-707.

21. sBiodiversidade De parasitas intestinais em mamíferos silvestres De duas localidades do Estado De São Paulo. Brazil: Universidade Estadual de Campinas, 2010

22. Teodoro AKM. Estudo De parasitos intestinais e sanguíneos em Didelphis spp. capturados em área urbana e em fragmentos de mata ciliar associados à bacia do Rio Capivari no município de Monte Mor São Paulo, Brasil. Universidade Estadual de Campinas, Brazil; 2013.

23. Travassos L. Sobre as espécies brasileiras da subfamília Heterakinae Railliet \& Henry. Mem Inst Oswaldo Cruz. 1913;5(3):271-318.

24. Proença MC. Revisão do gênero Aspidodera Railliet \& Henry, 1912: (Nematoda: Subuluroidea). Mem Inst Oswaldo Cruz. 1937;32(3):427-438.

25. Santos CP, Lent H, Gomes DC. The genus Aspidodera Railliet and Henry, 1912 (Nematoda: Heterakoidea): Revision, new synonyms and key for species. Rev Brazil Biol. 1990;50(4):1017-1031.

26. Chagas-Moutinho VA, Oliveira-Menezes A, Cárdenas MQ, et al. Further description of Aspidodera raillieti (Nematoda: Aspidoderidae) from Didelphis marsupialis (Mammalia: Didelphidae) by light and scanning electron microscopy. Parasitol Res. 2007;101:1331-1336.

27. Chandler AC. Notes on the Helminth parasites of the opossum (Didelphis virginiana) in Southeast Texas, with descriptions of four new species. Proc U S Nat Mus. 1932;81:1-15.

28. Foster AO. Some helminths of the woolly opossum in Panama. Trans Am Microsc Soc. 1939;58(2):185-198.

29. Caballero E, Cerecero MC. Estudios helmintológicos de la región oncocercosa de México y de la República de Guatemala. Nematoda. Segunda parte. Anales Del Instituto de Biología. 1994;15:389-407.

30. Lombardero OJ, Moriena RA. Nuevos helmintos de la comadreja overa (Didelphis azarae) para la Argentina. Rev Med Vet Bs As 1973;54(4):315-320. 
31. Pinto RM, Gomes DC. Contribuição ao conhecimento da fauna helmintológica da Região Amazônica. Nematódeos. Atas Soc Biol Rio de Janeiro. 1976:74(1)

32. Aldes KJ. Helminths of the opossum Didelphis virginiana, in Southern Illinois, with a compilation of all helminths reported from this host in North America. J Helm Soc Wash. 1995;62(2):197-208.

33. Silva MGQ. Taxonomia dos helmintos parasitos De Didelphis albiventris Lund, 1841, capturados na região Da Pampulha, Belo Horizonte, MG. Brazil: Universidade Federal De Minas Gerais; 1995.

34. Vicente JJ, Rodrigues HO, Gomes DC, et al. Nematóides do Brasil Parte V: Nematóides de Mamíferos. Rev Bras Zool. 1997;4(1):1-452.

35. Silva MGQ, Costa HMA. Helminths of white-bellied opossum from Brazil. J Wildl Dis. 1999;35(2):371-374.
36. Noronha O, Vicente JJ, Pinto RM. Novos registros de nematóides em didelfídeos no Brasil. Annals of XV Congresso Latino-Americano de Parasitologia, XVII Congresso Brasileiro de Parasitologia e I Congresso da Sociedade Paulista de Parasitologia. J Bras Patol. 2001;37(4):223.

37. Valente AL, Paulsen RMM, Muller G. Helmintos gastrointestinais Da cuíca-de-cauda-grossa, Lutreolina crassicaudata (Mammalia: Marsupialia), no Rio Grande do Sul. Annals of XXVIII Congresso Brasileiro de Medicina Veterinária - Conbravet. Brazil; 2001.

38. Muller G, Langoni PQ, Michels GH, et al .Nematódeos em Didelphis albiventris(gambás) da região sul do Rio Grande do Sul. Annals of XIII Congresso Brasileiro de Parasitologia Veterinária \& I Simpósio Latino-Americano de Ricketisioses. Brasil, Rev Bras Parasitol Vet. 2004;13(1):259.

39. Schmidt GD. Oncicola martini spp. and other Archiacanthocephala for the Chaco Boreal, Paraguai. J Parasitol. 1977;63(3):508-510. 